\title{
Influence of Neutralization Attitude in Academic Dishonesty among Undergraduates
}

\author{
Chan Ling Meng ${ }^{1,2}$, Jamilah Othman ${ }^{1}$, Jeffrey Lawrence D'Silva ${ }^{3} \&$ Zoharah Omar ${ }^{1}$ \\ ${ }^{1}$ Faculty of Educational Studies, Universiti Putra Malaysia, Malaysia \\ ${ }^{2}$ Faculty of Business and Finance, Universiti Tunku Abdul Rahman, Malaysia \\ ${ }^{3}$ Institute for Social Science Studies, Universiti Putra Malaysia, Malaysia \\ Correspondence: Chan Ling Meng, Faculty of Business and Finance, Universiti Tunku Abdul Rahman (Perak \\ Campus), Jalan University, Bandar Barat, 31900 Kampar Perak, Malaysia. Tel: 90-12-928-6382. E-mail: \\ chanlm@utar.edu.my
}

Received: March 13, 2014 Accepted: April 25, 2014 Online Published: May 27, 2014

doi:10.5539/ies.v7n6p66 URL: http://dx.doi.org/10.5539/ies.v7n6p66

\begin{abstract}
Previous literature had proposed that individuals tend to use neutralization to motivate their decisions to engage in deviant behaviours. This indicated that even though students have strong motivations not to cheat may do so anyway after employing neutralizing strategies. Hence, this study attempted to examine the role of neutralization in influencing students' attitude towards academic dishonesty. Students tend to use neutralization technique in order to free themselves from feeling guilty in engaging academic dishonesty. Besides that, it also attempted to study the reasons behind college student academic cheating behaviours. This study employed 620 randomly selected students from six different academic institutions. Results supported that students who engaged in academic dishonesty differ significantly from those who did not engage in this deviant behaviour with respect to their tendency to neutralize cheating. Results showed that cheating and neutralization were positively correlated among students. Through the findings, it showed that the use of neutralization techniques explained why students acknowledged that cheating is wrong but still chose to do it anyway.
\end{abstract}

Keywords: neutralization attitude, academic dishonesty, students

\section{Introduction}

"It is ok for me to cheat, as everyone is cheating in order to get the distinction in the study..."

Confession of a student.

Due to the red warning signals raised from the recent ethical scandals in the learning institutions and in the workplace, the interest in ethical behaviour in academic study and academic dishonesty in particular has enhanced the interest among researchers. Academic dishonesty is not a new topic, indeed it has been extensively studied in the past (Graham et al., 1994; McCabe \& Trevino, 2002; Pullen, Ortloff, Casey, \& Payne, 2000; Williams \& Hosek, 2003). This epidemic phenomenon is increasing over the years, and it seems to be justified by the fact that academic dishonesty is normal among students (Williams \& Hosek, 2003). From the past studies, rates of academic dishonesty among undergraduate students have been consistently high, ranging from $13 \%$ to almost 95\% (Graham, Monday, O’Brien, \& Steffen, 1994; McCabe \& Trevino, 2002; Pullen, Ortloff, Casey, \& Payne, 2000; Williams \& Hosek, 2003)

Pottle (2012) pointed that due to the turbulence of economic conditions in the market, it causes the undergraduates to have more competition in entering the volatile job market. Hence, students attempted to develop certain unethical behaviour in academia in order to obtain better grade so that they will have better opportunities in the workplace. Students are aware of this unethical practice, however, they still engage in it, due to the influence of neutralization. Neutralization has changed students' attitude toward cheating. For students, even though they feel guilty to cheat, but with the present of neutralization, they are deflecting the blame in order to achieve the materialistic rewards - good fortune in the workplace.

Neutralization enables students to achieve their good grade with little or no consequences. This is a deflecting blame process, where it enables us to neutralize our wrongdoing with valid reasons or based on valid causes, 
such as difficulties in catching up the syllabus, and the lecturers are too strict in marking (Stone, Jawahar, \& Kisamore, 2010). Stone et al. (2010) suggested that those who engaging in academic dishonesty can find justification for the deviant behaviour they committed and therefore mitigate the cognitive dissonance of their behaviour.

By understanding how students perceive toward academic dishonesty and what are the influences in their decisions to engage in academic dishonesty may give an insight to academicians and researchers to discourage such deviant behaviour, and to promote academic integrity at different education levels.

Hence, this study attempted to study the behaviour and the neutralization attitude of undergraduates towards academic dishonesty. It also attempted to describe the relationship between neutralization attitude and academic dishonesty behavior.

\section{Literature Review}

As time passed, more and more studies were carried on the issues of neutralization attitude that students use to justify or rationale their deviant behaviour-academic dishonesty. Findings suggested that students with these deviant attitudes are more likely to engage in academic dishonesty. And, if they have justified their cheating actions once, these attitudes grow stronger.

Neutralizing attitudes cause students to cheat both directly and indirectly. The indirect influence becomes part of a constellation of factors that involve things like seeing other students cheat, whether the student is extrinsically motivated (cares more about grades than learning), and ineffective instruction along with a performance-oriented teaching style.

Blaming others and attributing problems to external sources are prime examples of neutralizing attitudes that enable cheating. "I don't have time to study because I have to work full time to pay for college." "Cheating doesn't hurt anybody else." "You can't get into med school without really high grades." "This teacher is a jerk and doesn't care if I learn the material or not."

\subsection{Academic Dishonesty}

Nuss (1984) defined academic dishonesty as a behaviour that resulted in students giving or receiving unauthorized assistance in an academic exercise or receiving credit for work which is not their own. This definition is broader by the study of Gehring and Pavela (1994), where they defined it as an intentional act of fraud, in which "a student seeks to claim credit for the work or efforts of another without authorization, or uses unauthorized materials or fabricated information in any academic exercise... [or] forgery of academic documents, intentionally impeding or damaging the academic work of others, or assisting other students in acts of dishonesty (pp. 5-6)".

As time passed, the definition of academic dishonesty is further strengthened and enhanced through various studies. De Lambart, Ellen, and Ferrell (2003) suggested that academic dishonesty involving various deviant behaviour that breached the rules and regulations of learning institutions. They pointed that this deviant behaviour is multifaceted, which based on the wealth of research that spoke to practices that could be deemed as cheating.

Graves (2008) acknowledged that academic dishonesty is a crucial academic disease as its powerful impact on the quality of education and the reliability of assessment. This deviant behaviour, not only bring the harms to students, but also the reputation of the learning institutions. Stone, Jawahar, and Kisamore (2009) furthered strengthened that students who cheat on tests are more likely to engage in dishonesty activities in the workplace to those who do not. Furthermore, Michaels and Miethe (1989) suggested that once undergraduates successfully engaging in such deviant behaviour and attaining the rewards of good grades they do not deserve, they tend to set up a pattern for future deception. Indeed, research on the nexus between academic dishonesty and fraudulent behaviour in the workplace demonstrates that individuals who cheat in college go on to behave unethically at work (Harding et al., 2007; Nonis \& Swift, 2001; Sims, 1993; Stone, Jawahar, \& Kisamore, 2009).

\subsection{Neutralization Techniques}

The concept of neutralization is originated from the study of Sykes and Matza (1957) in the field of criminology. Skyes and Matza (1957) defined neutralization is deflecting blame process, which it explained how a criminal legitimizing his/her dishonest behaviour rendering it neutral or no longer dishonesty. It represents the rationalization and justifications for unethical behavior used to deflect self-disapproval from others (Skyes \& Matza, 1957). Through this theory, it suggested that students, who neutralize express support for a societal norm, yet rationalize to permit to violate those norms. Through the process of neutralization, undergraduates will cheat 
without feeling inherently dishonesty, thereby eliminating a sense of guilt for the dishonest behavior.

Skyes and Matza (1957) proposed that in the process of neutralization, following methods are used by the delinquents justified their illegitimate behaviours as in Table 1.

Table 1. Method of neutralization theory

\begin{tabular}{|c|c|c|}
\hline Method & Explanation & Example \\
\hline $\begin{array}{l}\text { Denial } \\
\text { responsibility }\end{array}$ & $\begin{array}{l}\text { The offender will propose that they were victims of } \\
\text { circumstance or were forced into situations beyond their control }\end{array}$ & "It $\mathrm{v}$ \\
\hline Denial of injury & $\begin{array}{l}\text { The offender insists that their actions did not cause any harm or } \\
\text { damage }\end{array}$ & $\begin{array}{l}\text { "It wasn't a big deal. } \\
\text { They could afford the } \\
\text { loss" }\end{array}$ \\
\hline Denial of the victim & $\begin{array}{l}\text { The offender believes that the victim deserved whatever action } \\
\text { the offender committed. }\end{array}$ & "They had it coming" \\
\hline $\begin{array}{l}\text { Condemnation of the } \\
\text { condemners }\end{array}$ & $\begin{array}{l}\text { The offenders maintain that those who condemn their offense } \\
\text { are doing so purely out of spite, or are shifting the blame off of } \\
\text { themselves unfairly }\end{array}$ & $\begin{array}{l}\text { "You were just as bad } \\
\text { in your day" }\end{array}$ \\
\hline $\begin{array}{l}\text { Appeal to higher } \\
\text { loyalties }\end{array}$ & $\begin{array}{l}\text { The offender suggests that his or her offence was for the greater } \\
\text { good, with long term consequences that would justify their } \\
\text { actions, such as protection of a friend. }\end{array}$ & $\begin{array}{l}\text { "My friends needed } \\
\text { me. What was I going } \\
\text { to do?" }\end{array}$ \\
\hline
\end{tabular}

Past studies (Murdock \& Stephens, 2007) suggested that neutralization attitude has significant positively correlations with cheating behaviour, as students tend to engage in cheating even though they are aware that cheating is an unethical behaviour. But due to the various reasons, such as poor performance in class, difficulties of subject, cause them to rationalize this deviant behaviour as a legalize action. In the study of Storch et al. (2005), they suggested that students tended to use neutralization to justify and deflect the reasons for their morally ambiguous, unethical or unacceptable behaviors and for any blame they feel as a result of their behaviours. Rettinger and Kramer (2009) further strengthened that the presence of neutralization attitude is strongly correlated with academic dishonesty as in their study; they realized that with the presence of neutralization, students will not feel the guilt he or she normally would, with the example statement respondents shared "Everyone else is doing it" (Rettinger \& Kramer, 2009).

\subsection{Relationship between Academic Dishonesty and Neutralization Attitude}

From the review of past studies, neutralization attitudes showed significant relationship in influencing students in engaging in the academic dishonesty, like cheating in examination, and plagiarism.

Table 2. Review of past studies on academic dishonesty and neutralization attitude

\begin{tabular}{ll}
\hline Haines et al. (1986) & Neutralization attitudes significant correlated with students cheating behaviour \\
\hline $\begin{array}{l}\text { Daniel, Blount, and Ferrell } \\
\text { (1991) }\end{array}$ & A correlation was found between cheating and neutralization behaviours \\
$\begin{array}{l}\text { Kisamore, Stone, and Jawahar } \\
\text { (2007) }\end{array}$ & Dishonesty was framed positively by students. \\
Bernardi et al. (2004) & $\begin{array}{l}\text { Students tended to legalize their wrong doing as their peer groups are doing the } \\
\text { same deviant behaviour. }\end{array}$ \\
Ahmad et al. (2008) & Students admitted to cheat as everyone else was cheating \\
\hline
\end{tabular}

Through the findings, it suggested that the reasons students employed neutralization attitude in their cheating behaviour, included the lack of a threat of punishment (Ahmad, et al, 2008), peer influence (J. Storch, E. Storch, \& Clark, 2002; Whitley, 1998), irrelevant courses or assignments (Mudrock \& Stephens, 2007), difficulty of work and competitiveness (Ahmad et al., 2008), successful personal histories of cheating (Whitley, 1998), and 
efficiency (Daniel, Blount, \& Ferrell, 1991).

In addition, in the study of Daniel et al. (1991), it found significant gender differences in the usage of neutralization attitude. It was pointed that the male students reported cheating more often than female students, with male tended to cheat when they believe they can deny responsibility for their behaviour. In the study of Roig and Ballew (1994) suggested that attitude toward cheating could bear a relationship to actual cheating behaviours as of the finding that more tolerant attitudes toward cheating indicate greater incidences of cheating. Furthermore, Michaels and Miethe (1989) also pointed that cheating is learned behaviour, which motivated by a variety of pressures, has rewards and costs, and is normative, not deviant. Hence, it resulted that even though students are aware that cheating is a wrongdoing action, however, through neutralization, they managed to argue that in some special circumstances, cheating is an acceptable action. Therefore, it may suggest that neutralization seems to be common and normal among the students.

Past researchers (Nonis \& Swift, 1998; Kisamore et al., 2007) suggested that students may use more than one of the neutralization methods to neutralize some or all of the perceived costs associated with academic dishonesty when they have a positive image toward academic dishonesty. Hence, in this study, the following hypothesis is proposed:

H1: Cheating behaviour is negative significantly related with attitude of students toward cheating behavior.

$\mathrm{H} 2$ : Cheating behaviour is positive significantly related with attitude of students toward cheating behavior.

\section{Research Methodology}

The design of the study was correlational as researchers attempted to seek the relationship between cheating behaviour and neutralization attitude among the undergraduates. In this study, researchers used random sampling method and were drawn from the population of the undergraduates from six different universities in Malaysia. Total sampling for this study was 560 respondents. This group of respondents consisted of $50.2 \%$ of female undergraduates and $49.8 \%$ of male undergraduates. They came from two main stream of studies: Humanities $(51.9 \%)$ and Science (48.1\%). $45.5 \%$ were first year undergraduates, $21.1 \%$ second year, $17.7 \%$ third year and $15.6 \%$ final year undergraduates.

A self-administrated survey was used to collect the data about the neutralization attitude and academic dishonesty behaviour. A twenty five item modified questionnaire consisting of measurement on respondents' frequency in engaging cheating, assisting others in cheating was used. The questionnaire (refer to appendix) was developed from several past studies with some modifications in order to adapt to Malaysian culture, with 1 indicating never and 7 indicating many times. An example of the deviant behaviour sounded like this: "How frequent did you use signals to exchange answers during examinations?"

While for the variable of neutralization technique, an 11 item modified questionnaire (refer to appendix) Consisting of personal neutralization attitudes by Haines et al. (1986) was used. Respondents were required to indicate on scale 1 to scale 7 with 1 indicating that cheating is not at all justified and 7 indicating that cheating is completely justified. An example of the item is "Cheating is okay if someone does it to help a friend".

For the variable of attitude toward cheating, researchers used an adopted version of questionnaire from Stone et al. (2010). There are 8 items to evaluate undergraduates' belief in regard to this deviant behaviour, willingness to report cheating by others and assisting others in cheating.

After the data was collected, Pearson Product Moment Correlation was used to analysis the correlation with the variable of attitude and neutralization technique.

\section{Findings}

Based on the Table 3, it showed that the findings on the relationship between cheating behaviour with students' attitude toward this deviant behaviour. From Table 3, it showed that the correlation coefficient is negative (-.514) suggested that a negative correlation between cheating behaviour and attitude. The more cheating behaviour occurred, the less favourable attitude toward cheating.

Furthermore, the result also indicated that there is a large correlation between the two variables $(r=.514)$, suggesting that the relationship between cheating behaviour and attitude toward cheating is moderate. In addition, the coefficient of determination is 0.264 , which indicated that there a quite a respectable amount of variance explained when conducted in the social sciences.

Significance level, $\mathrm{p}<.05$, indicated that the relationship between cheating behaviour and attitude toward cheating behaviour is significant. 
Hence, it can conclude that there is a moderate and negative relationship between cheating behaviour with students' attitude toward cheating.

Table 3. Relationship between cheating behaviour with students' attitude toward cheating behavior

\begin{tabular}{cccc}
\hline & Mean Cheating Score & Mean Attitude Score \\
\hline \multirow{3}{*}{ Cheating Score } & Pearson Correlation & 1 & $-.514^{* *}$ \\
& Sig. (2-tailed) & & .008 \\
$\mathrm{~N}$ & 620 & 620 \\
\hline
\end{tabular}

While, from Table 4 , it showed that with the correlation coefficient is positive $(.589$, there is a positive correlation between cheating behaviour and neutralization attitude. The more neutralization characteristics among the students, the more frequent they engage in cheating behaviour. Furthermore, there is a medium correlation between the two variables $(\mathrm{r}=.589)$, suggesting that the relationship between cheating behaviour and attitude toward cheating is medium.

From Table 4 , based on the significance level, $\mathrm{p}<.05$, indicated that the relationship between cheating behaviour and attitude toward cheating behaviour is significant.

Table 4. Relationship between cheating behaviour with neutralization

\begin{tabular}{cccc}
\hline & Mean Cheating Score & Mean Neutralization \\
\hline Mean Cheating Score & Pearson Correlation & 1 & $.589^{* *}$ \\
& Sig. (2-tailed) & & .000 \\
$\mathrm{~N}$ & 620 & 620 \\
\hline
\end{tabular}

**. Correlation is significant at the 0.01 level (2-tailed).

\section{Discussion and Conclusion}

Based on the findings, the study supported the research hypothesis that cheating behaviour is negatively correlated with attitude toward cheating behaviour and positively correlated with neutralization attitude.

Students' attitude toward cheating behaviour was significantly negatively related to academic dishonesty. It is consistent with the past studies that have shown that as Students' attitude toward cheating behaviour increase when come to academic dishonesty (Graham et al., 1994; Whitley, 1998). Students who were more condemnatory of cheating were less likely to cheat.

Meanwhile, from the findings, it suggested that neutralization techniques were significantly and positively related to academic dishonesty. Students in this study used neutralizations to justify or rationalize their cheating. The findings in this study are consistent with the existing literature about academic dishonesty and neutralization (LaBeff et al., 1990; Storch et al., 2002). However, the results suggest that the conceptualization and application of neutralization theory applied here have limits.

Neutralization is a technique used by individuals to rationalize or justify their decisions in order to engage behaviours that they know to be wrong (Sykes \& Matza, 1957). Neutralization has been explored extensively in the cheating literature and has often been associated with increased cheating frequency (Haines et al., 1986; Smith \& Davis, 2004; Ward \& Beck, 1990), as was the case in the present study $(\mathrm{M}=2.11)$. In addition, neutralization also found to be significant moderate and positively correlated with academic dishonesty behaviour. This indicated that neutralization attitudes can increase the frequencies of students to engage in academic dishonesty, which causes them to more prefer to cheat when they believe it is ok for this deviant behaviour.

Neutralization theory can provide insight into the cognitive processes of undergraduates who engage in academic dishonesty, a behaviour considered deviant or delinquent in the university environment. Bernardi et al. (2004) 
surmised that these students engage in external attributions, or blame, to explain their abnormal behaviours and suggested that understanding the role of neutralization in cheating could indeed provide valuable insight for preventing cheating. These students might experience a threat to their "survival", academically speaking, and regard the rules of academic honesty as mere guidelines when their ability to remain in college is threatened by course grade problems.

The results of this study could potentially both facilitate cheating prevention and influence efforts to educate students who have been found guilty of academic dishonesty. The results might provide knowledge to influence how student affairs professionals and faculty think about students who cheat so that they could reach out to the students more effectively. This study investigating cheating from a cognitive, or critical thinking oriented, perspective could enable researchers to move toward a deeper understanding of the underlying causes of cheating behaviours to facilitate more effective prevention efforts on college campuses.

According to Pulvers and Diekhoff (1999), one of the reasons that students neutralize their academic dishonesty is the belief of "Everyone does it". This is further strengthened in this study, as students consider that it is a valid reason for this deviant behaviour. It showed that students perceived that cheating is not a really deviant behaviour, but more as an acceptable action due to external factors. Hence, neutralization attitudes are knows as valid behaviour in order to find justifications to their actions. As a conclusion, the findings suggested that context emerges as a very crucial influence in the decision to engage in academic dishonesty and the neutralization attitudes towards academic dishonesty are the main influences on the academic dishonesty.

\section{References}

Ahmad, Z., Simun, M., \& Mohammad, J. (2008). Malaysian university students' attitudes to academic dishonesty and business ethics. Asia Pacific Journal of Education, 28, 149-160. http://dx.doi.org/10.1080/02188790802040721

Bernardi, R., Giuliano, J., Komatsu, E., Potter, B., \& Yamamoto, S. (2004). Contrasting the Cheating Behaviors of College Students from the United States and Japan. Global Virtue Ethics Review, 5(4), 5-31.

Daniel, L. G., Blount, K. D., \& Ferrell, C. M. (1991). Academic dishonesty among teacher education students: A descriptive-correlation study. Research in Higher Education, 32, 703-724. http://dx.doi.org/10.1007/BF00974739

De Lambert, K., Ellen, N., \& Taylor, L. (2003). Prevalence of Academic Dishonesty in Tertiary Institutions: The New Zealand Story. Working Paper, Christchurch College of Education.

Gehring, D., \& Pavela, G. (1994). Issues and perspectives on academic integrity. Washington, D.C.: National Association of Student Personnel Administrators.

Graham, M. A., Monday, J., O’Brien, K., \& Steffen, S. (1994). Cheating at small colleges: An examination of student and faculty attitudes and behaviors. Journal of College Student Development, 35, 255-260.

Graves, S. M. (2008). Student Cheating Habits: A predictor of Workplace Deviance. Journal of Diversity Management, 3(1), 15-22.

Haines, V. J., Kiefhoss, G., M. LaBeff, E. E., \& Clark, R (1986). College cheating: Immaturity, lack of commitment, and neutralizing attitude. Research in Higher Education, 25, 342-354. http://dx.doi.org/10.1007/BF00992130

Harding, T. S., Mayhew, M. J., Finelli, C. J., \& Carpenter, D. D. (2007). The Theory of Planned Behavior as a model of academic dishonesty in engineering and humanities undergraduates. Ethics \& Behavior, 17, 255-279. http://dx.doi.org/10.1080/10508420701519239

Kisamore, J., Stone, T., \& Jawahar, I. (2007). Academic Integrity: The Relationship between Individual and Situational Factors on Misconduct Contemplations. Journal of Business Ethics, 75, 381-394. http://dx.doi.org/10.1007/s10551-006-9260-9

LaBeff, E. E., Clark, R. E., Haines, V. J., \& Diekhoff, G. M. (1990). Situational ethics and college student cheating. Sociological Inquiry, 60(2), 190-198. http://dx.doi.org/10.1111/j.1475-682X.1990.tb00138.x

McCabe, D. L., \& Trevino, L. K. (2002). Honesty and honor codes. Academe, 88(1), 37-41. http://dx.doi.org/10.2307/40252118

Michaels, J. W., \& Miethe, T. D. (1989). Applying theories of deviance to academic cheating. Social Science Quarterly, 70, 870-885

Murdock, T. B., \& Stephens, J. W. (2007). Is cheating wrong? Students' reasoning about academic dishonesty. In 
E. M. Anderman, \& T. B. Murdock (Eds.), Psychology of Academic Cheating (pp. 229-253). Burlington, MA: Elseview. http://dx.doi.org/10.1016/B978-012372541-7/50014-0

Nonis, S., \& Swift, C., O. (2001). An examination of the relationship between academic dishonesty and workplace dishonesty: A multi-campus investigation. Journal of Educational for Business, 77(2), 69-77. http://dx.doi.org/10.1080/08832320109599052

Nuss, E. (1984). Academic Integrity: Comparing Faculty and Student Attitudes, Improving College and University Teaching, 32(3), 140-144. http://dx.doi.org/10.1080/00193089.1984.10533862

Pottle, L. S. (2012). Critical Analysis and Synthesis of Academic Dishonesty [Electronic Version]. Ethics and Social Responsibility.

Pullen, R., Ortloff, V., Casey, S., \& Payne, J. B. (2000) Analysis of academic misconduct using unobtrusive research: A study of discarded cheat sheets. College Student Journal, 34(4), 616-625.

Pulvers, K., \& Diekhoff, G. M. (1999). The relationship between academic dishonesty and college classroom environment. Research in Higher Education, 40(4), 487-498. http://dx.doi.org/10.1023/A:1018792210076

Rettinger, D. A., \& Jordan, A. E. (2005). The relationship among religion, motivation, and college cheating: A natural experiment. Ethics \& Behavior, 15(2), 107-129. http://dx.doi.org/10.1207/s15327019eb1502_2

Roig, M., \& Ballew, C. (1994). Attitudes Toward Cheating of Self and Others by College Students and Professors, The Psychological Record, 44(1), 3-12.

Sims, R. (1993). The Relationship Between Academic Dishonesty and Unethical Business Practices, Journal of Education for Business, 68(4), 207-211. http://dx.doi.org/10.1080/08832323.1993.10117614

Smith, W. E., \& Davis, E. B. (2004). Transforming Organizations: A five dimensional process (In review). 3rd International Conference on Systems Thinking in Management ICSTM 04: Transforming Organizations to Achieve Sustainable Success, May 19-21, 2004, University of Pennsylvania, Philadephia PA.

Stone, T. H., Jawahar, I. M., \& Kisamore, J. L. (2010). Predicting Academic Misconduct Intentions and Behaviors Using the Theory of Planned Behaviors and Personality. Basic and Applied Social Psychological, 32, 35-45. http://dx.doi.org/10.1080/01973530903539895

Stone, T. H., Jawahar, I. M., \& Kisamore, J. L. (2009). Using the theory of Planned Behavior and Cheating justifications to predict academic misconduct. Career Development International, 14(3), 221-241. http://dx.doi.org/10.1108/13620430910966415

Storch, J., Storch, E., \& Clark, P. (2002). Academic Dishonesty and Neutralisation Theory: A Comparison of Intercollegiate Athletes and Non athletes. Journal of College Student Development, 43(6), 921-930.

Sykes, G., \& Matza, D. (1957) Techniques of Neutralization: A Theory of Delinquency. American Sociological Review, 22, 664-670. http://dx.doi.org/10.2307/2089195

Ward, D. A., \& Beck, W. L. (1990). Gender and dishonesty. Journal of Social Psychology, 130, 333-339. http://dx.doi.org/10.1080/00224545.1990.9924589

Whitley, B. E. (1998). Factors associated with cheating among college students: A review. Research in Higher Education, 39(3), 235-274. http://dx.doi.org/10.1023/A:1018724900565

Williams, M., \& Hosek, W. (2003). Strategies for reducing academic for reducing academic dishonesty. Journal of Legal Studies Education, 21, 87. http://dx.doi.org/10.1111/j.1744-1722.2003.tb00326.x

\section{Appendix}

Section A: Cheating Behavior

In university, how frequent you....

1) Lifting/Copying few sentences from a published or internet source but not given credit to the author?

2) Lifting/Copying from another student and turned in as your own assignment?

3) Adding \& abetting someone to cheat during examination?

4) Working with others on assignment when the lecturer asked for individual work?

5) Using notes during examination without the lecturer's permission? 
6) Receiving substantial help on assignment without the lecturer's permission?

7) Cheating during examination in any way?

8) Reducing the margin's width of the assignments to make it seem longer than it really was?

9) Telling the lecturer a false reason for missing class?

10) Telling the lecturer a false reason for missing sit for the examination?

11) Doing less work than your share in a group assignment?

12) Receiving the questions for an exam from an unauthorized source prior to taking it?

13) Looking at another student's paper during examination?

14) Allowing another student's to take an examination by using your name?

15) Preparing notes to take to examination, without using them?

16) Using sources for an assignment that were not included in your bibliography?

17) Using information from someone else' test, quiz or assignments with their knowledge?

18) Using signals to exchange answer during examinations?

19) Using false reasons for missing deadlines for assignment?

20) Glancing at someone's answer during the examination?

21) Providing test questions to someone yet to take the test?

22) Providing test answers to someone yet to take the test?

23) Giving a completed assignment to another student?

24) Receiving unpermitted help on an assignments?

25) Providing an untrue excuse to gain extra time on an assignment?

Section B: Neutralization

1) Cheating is okay if someone does it to help a friend.

2) Cheating is okay if the subject is too hard. No matter how much one studies one cannot understand the subject.

3) Cheating is okay if someone is danger of losing his/her scholarship due to low grades.

4) Cheating is okay if someone doesn't have time to study because he/she is working to pay for fee.

5) Cheating is okay because cheating doesn't hurt anyone.

6) Cheating is okay if everyone else seems to be cheating.

7) Cheating is okay if the students sitting around me make no attempt to cover up their papers and I can see their answers.

8) Cheating is okay if the lecturer doesn't seem to care if I learn the subject.

9) Cheating is okay if the lecturer acts like his / her course is the only one he is talking. Too much material is assigned.

10) Cheating is okay if the invigilator left the room to talk to someone during the test.

11) Cheating is okay if the course is required for my degree, but the information seems useless. I'm only interested in the grade.

\section{Copyrights}

Copyright for this article is retained by the author(s), with first publication rights granted to the journal.

This is an open-access article distributed under the terms and conditions of the Creative Commons Attribution license (http://creativecommons.org/licenses/by/3.0/). 